\title{
Hydrogen peroxide release and hydroxyl radical formation in mixtures containing mineral fibres and human neutrophils
}

\author{
Per Leanderson, Christer Tagesson
}

\begin{abstract}
The ability of different mineral fibres (rock wool, glass wool, ceramic fibres, chrysotile A, chrysotile $B$, amosite, crocidolite, antophyllite, erionite, and wollastonite) to stimulate hydrogen peroxide $\left(\mathrm{H}_{2} \mathrm{O}_{2}\right)$ and hydroxyl radical ( $\mathrm{OH}^{*}$ ) formation in mixtures containing human polymorphonuclear leucocytes (PMNLs) was investigated. In the presence of azide, all the fibres caused considerable $\mathrm{H}_{2} \mathrm{O}_{2}$ formation, and about twice as much $\mathrm{H}_{2} \mathrm{O}_{2}$ was found in mixtures with the natural fibres (asbestos, erionite, and wollastonite) than in mixtures with the manmade fibres (rock wool, glass wool, and ceramic fibres). In the presence of externally added iron, all the fibres were found to generate $\mathrm{OH}^{\circ}$ and the natural fibres caused about three times more $\mathrm{OH}$ formation than the manmade fibres. In the absence of external iron, there was less OH' formation; however, amosite, crocidolite, antophyllite, erionite, and wollastonite still generated considerable amounts of $\mathrm{OH}^{*}$, also under circumstances in which only small amounts of $\mathrm{OH}^{\cdot}$ were produced in mixtures with the manmade fibres. These findings indicate that natural fibres generate more $\mathrm{H}_{2} \mathrm{O}_{2}$ and $\mathrm{OH}^{\circ}$ than manmade fibres when incubated with PMNLs in the presence of external iron. They also suggest that the natural fibres, amosite, crocidolite, antophyllite, erionite, and wollastonite may act catalytically in the dissociation of $\mathrm{H}_{2} \mathrm{O}_{2}$ to $\mathrm{OH}^{-}$in the absence of external iron, whereas manmade fibres such as rock wool, glass wool, and ceramic fibres, do not seem to be able to generate $\mathrm{OH}^{\circ}$ in the absence of external iron.
\end{abstract}

(British Journal of Industrial Medicine 1992;49:745-749)

Departments of Occupational Medicine and Clinical Chemistry, Faculty of Health Sciences, S-581 85 Linköping, Sweden

P Leanderson, C Tagesson
A number of recent findings support the hypothesis that reactive oxygen metabolites play an important part in the toxic effects of asbestos and other mineral fibres. ${ }^{1}$ For example, asbestos has been shown to catalyse the dissociation of $\mathrm{H}_{2} \mathrm{O}_{2}$ to $\mathrm{OH}^{\cdot},{ }^{2}$ and $\mathrm{OH}^{-}$ formation has also been found in aqueous buffers containing asbestos without $\mathrm{H}_{2} \mathrm{O}_{2}{ }^{3}$ In these two studies, iron was considered important for catalytic activity in generation of $\mathrm{OH}^{-}$. Exposure of the murine fibroblast cell line, $\mathrm{C} 3 \mathrm{H} 10 \mathrm{~T} 1 / 2$ to crocidolite fibres has been shown to induce both lipid peroxidation and DNA strand breaks, both of which were attenuated after the fibres had been pretreated with the iron chelator, desferrioxamine, which makes the iron catalytically inactive. ${ }^{4}$ It was thus concluded that iron mediated damage to cells could be an important mechanism in pathogenicity of asbestos.

Reactive oxygen metabolites can be generated by stimulated PMNLs, and mineral fibres can stimulate PMNLs to generate large amounts of reactive oxygen metabolites. This has previously been shown with chemoluminesence techniques. ${ }^{56} \mathrm{We}$ recently used deoxyguanosine (dG) to trap $\mathrm{OH}^{-}$generated by human PMNLs activated with the tumour promoter, phorbol myristate acetate, in the presence of chelated iron (Fe(III)-EDTA). ${ }^{7}$ In this system the generated $\mathrm{OH}^{-}$reacts with dG under the formation of 8 -hydroxydeoxyguanosine $(8 \mathrm{OHdG})$, which is analysed using high performance liquid chromatography. ${ }^{8}$ In the present study, we have used deoxyguanosine as a trapping agent to detect formation of $\mathrm{OH}^{\cdot}$ after stimulation of PMNLs with different mineral fibres. We have also measured the $\mathrm{H}_{2} \mathrm{O}_{2}$ formation after treatment of human PMNLs with different types of mineral fibres, and investigated if certain mineral fibres may act as electron donators and catalyse the dissociation of $\mathrm{H}_{2} \mathrm{O}_{2}$ to $\mathrm{OH}^{\cdot}$ without the need of $\mathrm{Fe}$ (III)-EDTA.

\section{Materials and methods}

MATERIALS

Asbestos (IUCC standard fibres), wollastonite, and erionite fibres were kindly provided by $\mathrm{Dr}$ Henri Pezerat, Laboratoire De Réactivité de Surface et 

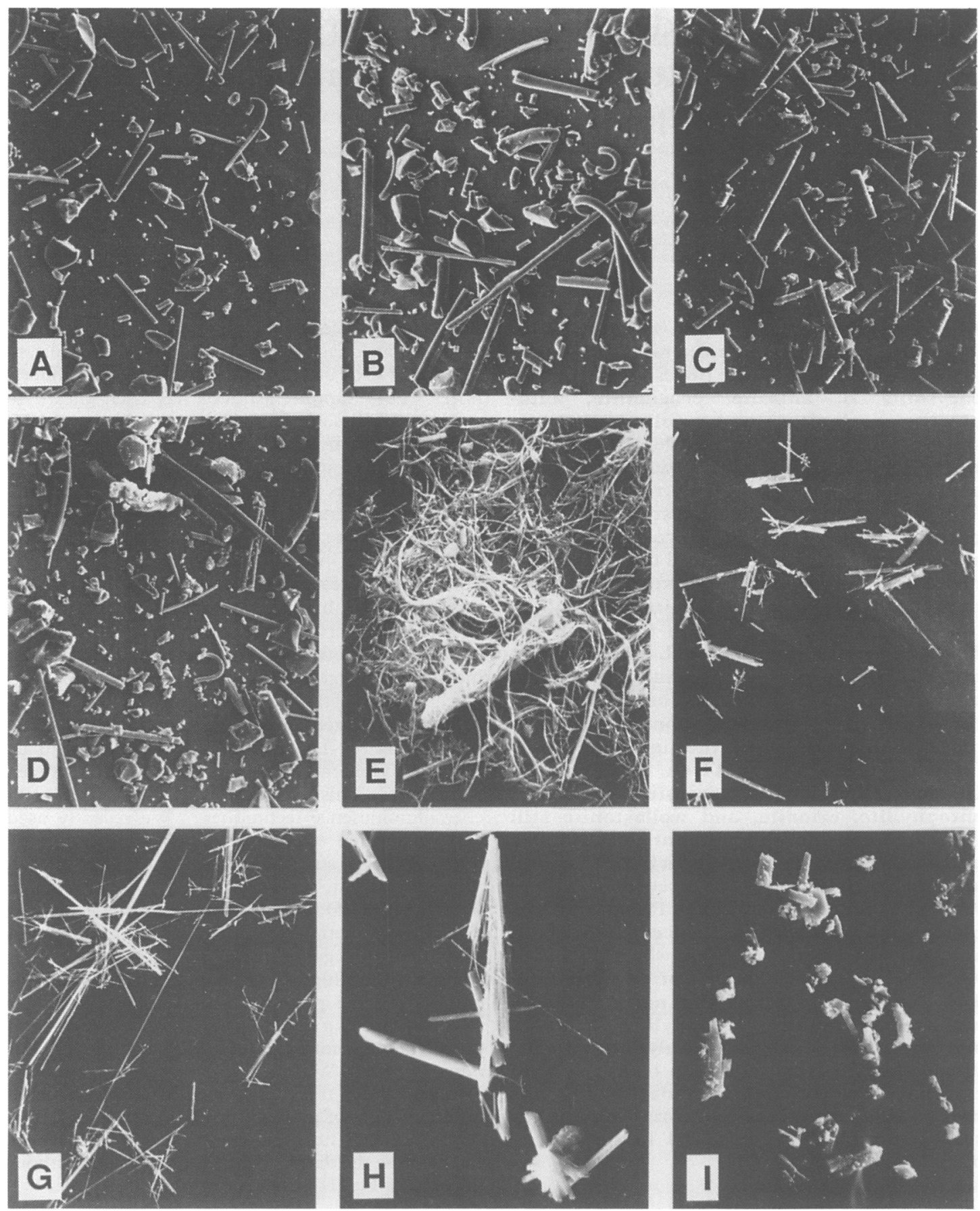

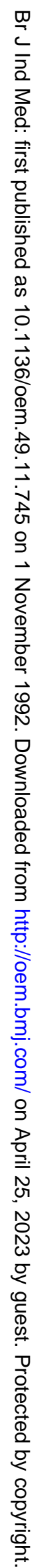


Structure, Université $P$ et $M$ Curie, Paris, France. The rock wool and glass wool samples were kind gifts from Mr Ingemar Öhberg, Rockwool AB, Skövde, Sweden, and the ceramic fibre (Kerlane ${ }^{\bar{R}}$ ) was kindly provided by $\mathrm{Mr}$ Sigurd Granberg, Bolin \& Löfgren AB, Lidköping, Sweden. Rockwool I contained more iron than rock wool II. Figure 1 shows scanning electron micrographs of the different fibres.

2'-Deoxyguanosine was purchased from Serva Feinbiochemica GMBH, Heidelberg, Germany. 8Hydroxydeoxyguanosine was synthesised in our laboratory according to a method described by Kasai and Nishimura. ${ }^{9}$ Iron(III)chloride and EDTA (disodium) were from Merck, Darmstadt, Germany, and Ficoll-Hypaque from Flow Laboratories, Rickmansworth, England. Scopoletin and sodium azide were from Sigma, St Louis, USA and horse radish peroxidase (HRP) was from Boehringer Mannheim, Germany. Phosphate buffered saline (PBS) was prepared in our own laboratory and contained $137 \mathrm{mM} \mathrm{NaCl}$, $2.7 \mathrm{mM} \mathrm{KCl}, 8.1 \mathrm{mM} \mathrm{Na} 2 \mathrm{HPO}_{4}, 1 \cdot 15 \mathrm{mM} \mathrm{KH}_{2} \mathrm{PO}_{4}$, pH 7.4 (PBS I); PBS II was similar to PBS I but also contained $0.90 \mathrm{mM} \mathrm{CaCl}_{2}$ and $0.49 \mathrm{mM} \mathrm{MgCl}_{2}$.

Deoxyguanosine was diluted with PBS II to a $10 \mathrm{mM}$ stock solution and stored at $-20^{\circ} \mathrm{C}$ until use. The EDTA was prepared as a $20 \mathrm{mM}$ solution in distilled water and the $\mathrm{pH}$ was adjusted to 7.4 with sodium hydroxide. Just before use, $2 \cdot 7 \mathrm{mg}$ iron(III)chloride was dissolved in $1 \mathrm{ml} 20 \mathrm{mM}$ EDTA resulting in a $10 \mathrm{mM} \mathrm{Fe}$ (III) solution with an $\mathrm{Fe}$ (III)EDTA ratio of $1: 2$.

Neutrophils were isolated from venous blood as described elsewhere. ${ }^{7}$

\section{EXPERIMENTAL STUDIES}

The rock wool, glass wool, and ceramic fibre were crushed for one minute in an agate mortar not more than 15 minutes before the experiments. All fibres were suspended in PBS II to give a $2 \mathrm{mg} / \mathrm{ml}$ stock solution immediately before the mixing with PMNLs. Reaction mixtures for studying $\mathrm{H}_{2} \mathrm{O}_{2}$ formation contained $100 \mu \mathrm{l}$ cell suspension (500 000 cells), $50 \mu \mathrm{l}$ fibre suspension $(2 \mathrm{mg} / \mathrm{ml})$, and $100 \mu \mathrm{l}$ $5 \mathrm{mM}$ sodium azide, all dissolved in PBS II to a final volume of $500 \mu \mathrm{l}$. Reaction mixtures for studying $\mathrm{OH}^{\cdot}$ formation contained $50 \mu \mathrm{l} 10 \mathrm{mM} \mathrm{dG}, 100 \mu \mathrm{l}$ cell suspension containing 500000 PMNLs, fibres $(50-1000 \mu \mathrm{g} / \mathrm{ml})$ with or without $5 \mu 110 \mathrm{mM}$ ironEDTA, and $100 \mu \mathrm{l} 5 \mathrm{mM}$ sodium azide in PBS II (total volume $500 \mu \mathrm{l}$ ). Mixtures were incubated in $1.5 \mathrm{ml}$ Eppendorf tubes placed in a slow rotator in darkness at $37^{\circ} \mathrm{C}$. After 20 minutes of incubation, the reaction was stopped by two minutes centrifugation at $14000 \mathrm{~g}$ at $4^{\circ} \mathrm{C}$ in an Eppendorf Centrifuge 5402, and $\mathrm{H}_{2} \mathrm{O}_{2}$ or $8 \mathrm{OHdG}$ was analysed as described next.

\section{ANALYSIS}

Hydrogen peroxide was analysed with a modified version of the method described by Corbett. ${ }^{10}$ After centrifugation, $300 \mu \mathrm{l}$ of the supernatant was collected and mixed with $100 \mu \mathrm{l} 0 \cdot 2 \mathrm{M}$ sodium acetate containing $1 \mathrm{mM}$ EDTA, $25 \mu \mathrm{l} 50 \mu \mathrm{M}$ scopoletin, and $25 \mu \mathrm{l} \mathrm{HRP}$ (50 Units/ml). After five minutes at room temperature in subdued light, the reaction was stopped by addition of $250 \mu \mathrm{l} 0.3 \mathrm{M}$ potassium borate, $\mathrm{pH}$ 10. Fluorescence measurements were carried out on a Perkin Elmer 3000 fluorescence spectrophotometer with excitation and emission wavelengths of 395 and $470 \mathrm{~nm}$ respectively. The standard curve was linear up to $5 \mu \mathrm{M} \mathrm{H}_{2} \mathrm{O}_{2}$.

Measurement of $8 \mathrm{OHdG}$ was by high performance liquid chromatography and electrochemical detection as originally described by Floyd et al. ${ }^{8}$ The equipment has been described elsewhere. ${ }^{11}$

The results presented represent the mean (SD) of at least three different experiments.

\section{Results}

Table 1 shows the formation of $\mathrm{H}_{2} \mathrm{O}_{2}$ in mixtures of PMNLs and different fibres. Both manmade and natural fibres caused a substantial formation and release of $\mathrm{H}_{2} \mathrm{O}_{2}$ into the medium, but the natural fibres generally released more $\mathrm{H}_{2} \mathrm{O}_{2}(0.39-0.81 \mathrm{nmol})$ than the manmade fibres $(0.07-0.31 \mathrm{nmol}) . \mathrm{No}_{2} \mathrm{O}_{2}$ could be detected in the absence of sodium azide.

Figure 2 shows the formation of $80 \mathrm{HdG}$ in mixtures containing fibres, PMNLs, Fe(III)-EDTA, azide, and dG. Both manmade mineral fibres and natural mineral fibres stimulated generation of $8 \mathrm{OHdG}$ in a dose dependent manner, but the asbestos fibres, wollastonite, and erionite were more active than the manmade mineral fibres.

Table 2 shows the formation of $80 \mathrm{OHG}$ in mixtures containing fibres $(200 \mu \mathrm{g} / \mathrm{ml})$, PMNL, and dG, with or without $\mathrm{Fe}$ (III)-EDTA. In mixtures containing $\mathrm{Fe}$ (III)-EDTA supplemented with azide, the

Table 1 Formation of $\mathrm{H}_{2} \mathrm{O}_{2}$ in mixtures containing PMNLs and different mineral fibres

\begin{tabular}{ll}
\hline & $\mathrm{H}_{2} \mathrm{O}_{2}$ formation $(\mathrm{nmol})$ \\
\cline { 2 - 2 } Fibre type & Mean $(\mathrm{SD})$ \\
\hline Rock wool I & $0.20(0 \cdot 15)$ \\
Rock wool II & $0.31(0.08)$ \\
Glass wool & $0.29(0 \cdot 1 \mathrm{0})$ \\
Ceramic fibre & $0.07(0.05)$ \\
Chrysotile A & $0.44(0 \cdot 12)$ \\
Chrysotile B & $0.43(0 \cdot 07)$ \\
Amosite & $0.59(0 \cdot 08)$ \\
Crocidolite & $0.46(0.07)$ \\
Antophyllite & $0.81(0 \cdot 13)$ \\
Erionite & $0.39(0 \cdot 15)$ \\
Wollastonite & $0.54(0.11)$ \\
\hline
\end{tabular}

The generation of $\mathrm{H}_{2} \mathrm{O}_{2}$ in mixtures without fibres was less than $0.05 \mathrm{nmol}$. Values are from three experiments. 


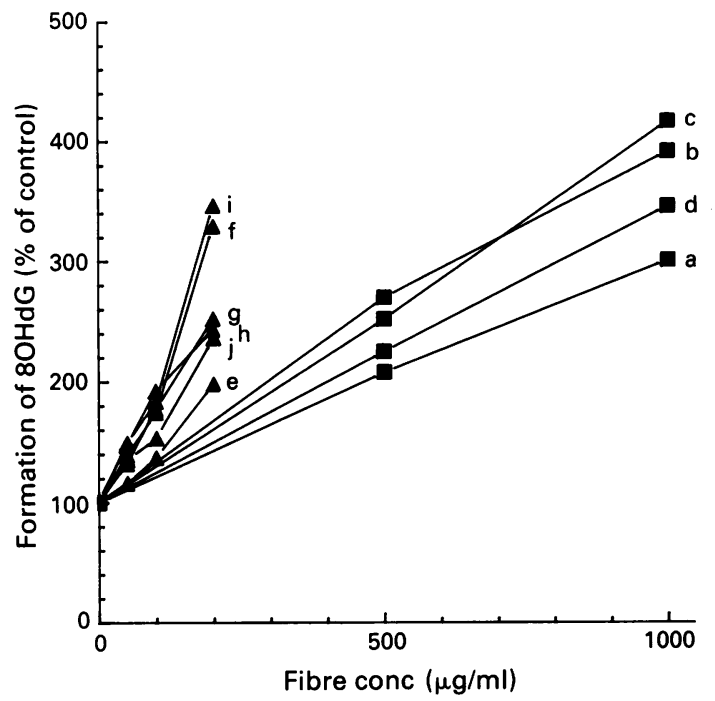

Figure 2 Formation of $80 \mathrm{HdG}$ in mixtures containing $P M N L s, d G, F e(I I I)-E D T A$ and different fibres: Rock wool $I(a)$, rock wool II (b), glass wool (c), ceramic fibre (d), chrysotile $A(e)$, chrysotile $B(f)$, amosite $(g)$, crocidolite $(h)$, antophyllite (i), and erionite ( $j)$. Each point is the mean of three experiments.

natural fibres produced $2 \cdot 8-21$ pmol $8 \mathrm{OHdG} / 10^{3}$ PMNLs compared with $0 \cdot 7-5$ pmol $8 \mathrm{OHdG} / 10^{5}$ PMNLs in mixtures containing manmade mineral fibres. Without addition of azide the formation of $8 \mathrm{OHdG}$ was less in all the samples. In the absence of chelated iron (table 2 right) the $80 \mathrm{HdG}$ formation was $0 \cdot 2-0.4 \mathrm{pmol} 8 \mathrm{OHdG} / 10^{5}$ PMNLs and $0.8-$ $2 \cdot 8 \mathrm{pmol} 8 \mathrm{OHdG} / 10^{5}$ PMNLs for the manmade and natural fibres respectively. In the absence of both chelated iron and azide the formation of $8 \mathrm{OHdG}$ was less prominent and only $0 \cdot 1-0.2$ and $0.8-1.7 \mathrm{pmol}$ $8 \mathrm{OHdG} / 10^{5}$ PMNLs was produced in mixtures containing manmade mineral fibres and natural fibres respectively.

\section{Discussion}

Exposure to asbestos and asbestiform fibres is associated with asbestosis, mesothelioma, and lung cancer. ${ }^{12}$ Also synthetic fibres such as rock wool, glass wool, and ceramic fibres have been found to be carcinogenic in animal studies ${ }^{13}$ and large epidemiological studies have shown that workers in the rock wool and glass wool manufacturing industry have an increased risk of developing lung cancer. ${ }^{14}$ In the past years, much attention has been drawn to the role of reactive oxygen metabolites in the toxic and carcinogenic potential of mineral fibres. ${ }^{1}$ Reactive oxygen metabolites are known to be generated both by fibres alone $e^{715}$ and by inflammatory cells such as PMNLs that accumulate in the lung after exposure to fibres. The association of inflammation with a variety of epithelial malignancies has been known for a long time and the role of PMNL generated oxidants in carcinogenesis is now generally acknowledged. ${ }^{16}$ Oxidants derived from PMNLs are able to damage DNA in neighbouring cells in vitro ${ }^{17}$ and have also been shown to generate malignant transformation in animals. ${ }^{18}$ Also, $\mathrm{H}_{2} \mathrm{O}_{2}$ has been found to be mutagenic to cultured cells ${ }^{1920}$ and to cause squamous metaplasia in hamster tracheal explants. ${ }^{21}$ Superoxide anions and $\mathrm{H}_{2} \mathrm{O}_{2}$ in concentrations present physiologically in the vicinity of activated phagocytes have recently also been found to increase the activity of ornithine decarboxylase in hamster tracheal explants and it was concluded that $\mathrm{H}_{2} \mathrm{O}_{2}$ may play an important part in proliferation of respiratory epithelial cells by altering the regulation of the gene coding for ornitine decarboxylase. ${ }^{22}$

The aim of the present study was to investigate if mineral fibres can stimulate PMNLs to release $\mathrm{H}_{2} \mathrm{O}_{2}$ and act as catalysts in the formation of $\mathrm{OH}$. All fibres investigated stimulated PMNLs to release $\mathrm{H}_{2} \mathrm{O}_{2}$, which could be detected in the presence of azide (table 1). Formation of $\mathrm{OH}^{*}$ was demonstrated in mixtures of PMNLs and fibres when Fe(III)-EDTA was present (fig 2, table 2 ) and addition of azide to the

Table 2 Formation of $8 O H d G$ in mixtures containing PMNLs, $d G$, and different mineral fibres

\begin{tabular}{|c|c|c|c|c|}
\hline \multirow[b]{3}{*}{ Fibre } & \multicolumn{4}{|l|}{$8 O H d G^{\star}$} \\
\hline & \multicolumn{2}{|c|}{$+F e(I I I)-E D T A$} & \multicolumn{2}{|c|}{$-F e(I I I)-E D T A$} \\
\hline & $\begin{array}{l}+ \text { azide } \\
\text { Mean (SD) }\end{array}$ & $\begin{array}{l}\text {-azide } \\
\text { Mean (SD) }\end{array}$ & $\begin{array}{l}+ \text { azide } \\
\text { Mean (SD) }\end{array}$ & $\begin{array}{l}\text {-azide } \\
\text { Mean (SD) }\end{array}$ \\
\hline $\begin{array}{l}\text { Rock wool I } \\
\text { Rock wool II } \\
\text { Glass wool } \\
\text { Ceramic fibre }\end{array}$ & $\begin{array}{l}2.0(0.6) \\
2.4(0.8) \\
5.0(2 \cdot 8) \\
0.7(0.4)\end{array}$ & $\begin{array}{l}1.2(0.1) \\
1.4(0.4) \\
2.9(1.4) \\
0.6(0.4)\end{array}$ & $\begin{array}{l}0.2(0.1) \\
0.4(0.4) \\
0.2(0.1) \\
0.3(0.1)\end{array}$ & $\begin{array}{l}0.2(0.3) \\
0.1(0.4) \\
0.1(0.1) \\
0.2(0.1)\end{array}$ \\
\hline $\begin{array}{l}\text { Chrysotile A } \\
\text { Chrysotile B } \\
\text { Amosite } \\
\text { Crocidolite } \\
\text { Antophyllite }\end{array}$ & $\begin{array}{r}2.8(0.1) \\
4.6(0.7) \\
4.6(0.4) \\
6.3(0.4) \\
21.0(0.7)\end{array}$ & $\begin{array}{r}2.5(0.1) \\
2.6(0.1) \\
2.5(0.3) \\
3.5(0.1) \\
13.0(0.4)\end{array}$ & $\begin{array}{l}0.8(0.2) \\
1.3(0.1) \\
1.1(0.1) \\
1.5(0.1) \\
2.8(0.3)\end{array}$ & $\begin{array}{l}0.7(0.2) \\
0.5(0.3) \\
1.1(0.1) \\
0.8(0.2) \\
1.0(0.3)\end{array}$ \\
\hline $\begin{array}{l}\text { Erionite } \\
\text { Wollastonite }\end{array}$ & $\begin{array}{l}7 \cdot 1(0.6) \\
6.2(0.6)\end{array}$ & $\begin{array}{l}2.5(0.2) \\
3.4(0.1)\end{array}$ & $\begin{array}{l}1.0(0.2) \\
1.3(0.4)\end{array}$ & $\begin{array}{l}1.0(0.2) \\
1.7(0.4)\end{array}$ \\
\hline
\end{tabular}

^Formation of $8 \mathrm{OHdG}$ (pmol/10 $\left.10^{5} \mathrm{PMNL}\right)$. Values are from three experiments. 
reaction mixtures increased the formation of $\mathrm{OH}^{\cdot}$ (table 2). This was probably due to inhibition of myeloperoxidase, which has been found to decrease the formation of $\mathrm{OH}^{-}$in similar experimental systems. ${ }^{2324}$ A considerable decrease in $\mathrm{OH}^{\cdot}$ formation was found in fibre PMNL mixtures without $\mathrm{Fe}$ (III)EDTA (table 2, right). There was little formation of $\mathrm{OH}^{\cdot}$ in mixtures with manmade mineral fibres, indicating that these fibres themselves are unable to catalyse the dissociation of $\mathrm{H}_{2} \mathrm{O}_{2}$ to $\mathrm{OH}^{-}$in mixtures containing PMNLs. By contrast, the $\mathrm{OH}^{*}$ formation in mixtures with asbestos, erionite, and wollastonite indicate that these natural mineral fibres are able to catalyse $\mathrm{OH}^{\cdot}$ formation in vitro, both in the absence and presence of azide. The iron content, which has been shown to be important for the biochemical and biological effects of asbestos in other studies, ${ }^{25} \mathrm{did}$ not affect the formation of $\mathrm{OH}^{*}$ in this experimental system. Thus fibres containing iron, such as crocidolite, amosite, antophyllite, and rock wool, did not generate more $\mathrm{OH}^{\cdot}$ than did erionite, wollastonite chrysotile, glass wool, and ceramic fibres, which contain only trace amounts of iron.

The risk of developing lung fibrosis, lung cancer, and mesothelioma during occupational exposures to most manmade mineral fibres is considered low, ${ }^{26}$ whereas asbestos fibres and asbestiform fibres like erionite are associated with higher risks of developing cancer or fibrosis. ${ }^{12}$ It is possible that these diseases, at least in part, are due to inflammatory reactions and subsequent formation of reactive oxygen metabolites close to the epithelial or mesothelial cells. Exposure of the lung to mineral fibres results in a rapid increase in the number of PMNLs ${ }^{27}$ and one might speculate that fibres that can both increase the formation of $\mathrm{H}_{2} \mathrm{O}_{2}$ and catalyse the dissociation of $\mathrm{H}_{2} \mathrm{O}_{2}$ to $\mathrm{OH}^{\cdot}$ would be more hazardous than other more inert fibres. This study indicates that some natural fibres are able to catalyse $\mathrm{OH}^{\cdot}$ formation in an experimental in vitro system containing PMNLs. This may increase their toxic effects and could be important both for malignant and non-malignant respiratory disorders, such as pleural plaque and fibrosis, which are all associated with fibre induced inflammation.

This work was supported by the Swedish Work Environment Fund (89-1335).

Requests for reprints to: Per Leanderson, Department of Occupational Medicine, Faculty of Health Sciences, S-581 85 Linköping, Sweden.

1 Mossman BT, Marsh JP. Evidence supporting the role for active oxygen species in asbestos-induced toxicity and lung disease. Environ Health Perspect 1989;81:91-4.

2 Weitzman SA, Graceffa P. Asbestos catalyzes hydroxyl and superoxide radical generation from hydrogen peroxide. Arch Biochem Biophys 1984;228:373-6.

3 Zalma R, Bonneau L, Jaurand MC, Guignard J, Pezerat H.
Formation of oxy-radicals by oxygen reduction arising from the surface activity of asbestos. Canadian Journal of Chemistry 1987;65:2338-41.

4 Turver CJ, Brown RC. The role of catalytic iron in asbestos induced lipid peroxidation and DNA-damage in C3H10T $1 / 2$ cells. Br J Cancer 1987;56:133-6.

5 Hedenborg $M$, Klockars $M$. Production of reactive oxygen metabolites induced by asbestos fibres in human polymorphonuclear leucocytes. J Clin Pathol 1987;40:1189-93.

6 Hansen K, Mossmann BT. Generation of superoxide $\left(\mathrm{O}_{\bar{\xi}}^{-}\right)$from alveolar macrophages exposed to asbestiform and non nonfibrous particles. Cancer Res 1987;41:1681-6.

7 Leanderson P, Tagesson C. Rapid and sensitive detection of hydroxyl radicals formed by activated neutrophils in the presence of chelated iron: Hydroxylation of deoxyguanosine to 8-hydroxydeoxyguanosine. Agents Actions 1992;36:50-7.

8 Floyd RA, Watson JJ, Wong PK, Altmiller DH, Rickard RC. Hydroxyl radical free adduct of deoxyguanosin: Sensitive detection and mechanism of formation. Free Radical Research Communication 1986;1:163-72.

9 Kasai H, Nishimura S. Hydroxylation of deoxyguanosine at the C-8 position by ascorbic acid and other reducing agents. Nucleic Acids Res 1984;12:2137-45.

10 Corbett JT. The scopoletin assay for hydrogen peroxide: A review and a better method. J Biochem Biophys Methods 1989;18:297-308.

11 Leanderson P, Söderkvist P, Tagesson C. Hydroxyl radical mediated DNA base modefication by manmade mineral fibres. Br J Ind Med 1989;46:435-8.

12 Brown RC, Hoskins JA, Miller K, Mossman BT. Pathogenetic mechanisms of asbestos and other mineral fibres. Molecular Aspects of Medicine 1990;11:325-49.

13 Wheeler CS. Exposure to man-made mineral fibers: A summary of current animal data. Toxicol Ind Health 1990;6:293-307.

14 Doll R. Symposium on MMMF, Copenhagen, October 1986: Overview and conclusions. Ann Occup Hyg 1987;31:805-19.

15 Pezerat $\mathrm{H}$, Zalma R, Guignard J. Production of oxygen radicals by the reaction of oxygen arising from the surface activity of mineral fibres. In: Bignon J, Peto J, Saracci R, eds. Nonoccupational exposure to mineral fibres. Lyon: International Agency for Research on Cancer, 1989;100-11. (IARC sci publ No 90.)

16 Weitzman SA. Inflammation and cancer: role of phagocytegenerated oxidants in carcinogenesis. Blood 1990;76:655-63.

17 Shacter E, Beecham EJ, Covey JM, Kohn KW, Potter M. Activated neutrophils induce prolonged DNA damage in neighboring cells. Carcinogenesis 1988;9:2297-304.

18 Weitzman SA, Weitberg AB, Clark EP, Stossel TP. Phagocytes as carcinogens: Malignant transformation produced by human neutrophils. Science 1984;227:1231-3.

19 Nassi-Calò L, Mello-Fihlo AC, Meneghini R. o-Phenantroline protects mammalian cells from hydrogen peroxide-induced gene mutation and morphological transformation. Carcinogenesis 1989;10:1055-7.

20 Moraes EC, Keyse SM, Tyrrell RM. Mutagenesis of hydrogen peroxide treatment of mammalian cells: A molecular analysis. Carcinogenesis 1990;11:283-93.

21 Radosevich CA, Weitman SA. Hydrogen peroxide induces squamous metaplasia in a hamster tracheal organ explant culture model. Carcinogenesis 1989;10:1943-6.

22 March JP, Mossmann BT. Role of asbestos and active oxygen species in activation and expression of ornitine decarboxylase in hamster tracheal epithelial cells. Cancer Res 1991;51: 167-73.

23 Winterbourn CC. Myeloperoxidase as an effective inhibitor of hydroxyl radical production: Implications for the oxidative reactions in neutrophils. $J$ Clin Invest 1986;78:545-50.

24 Britigan BE, Hassett GM, Rosen DR, Hamill DR, Cohen MS Neutrophil degranulation inhibits potential hydroxyl-radical formation. Biochem J 1989;246:447-55.

25 Lund LG, Aust AE. Iron-catalyzed reactions may be responsible for the biochemical and biological effects of asbestos. Bio Factors 1991;3:83-89.

26 Lippmann M. Man-made mineral fibers (MMMF): Human exposures and health risk assessment. Toxicol Ind Health 1990; 6:225-46.

27 Schoenberger CI, Hunninghake GW, Kawanami O, Ferrans VJ, Crystal RG. Role of alveolar macrophages in asbestosis: modulation of neutrophil migration to the lung after acute asbestos exposure. Thorax 1982;37:803-9.

Accepted 11 May 1992 